\title{
APLIKASI TEKNOLOGI 3D PRINTER DALAM RANGKA PENGEMBANGAN PEMBUATAN KOMPONEN MINIATUR DI KARANG TARUNA DUSUN BENDUNGAN
}

\author{
Braam Delfian Prihadianto*, Suryo Darmo \\ Departemen Teknik Mesin Sekolah Vokasi Universitas Gadjah Mada \\ Jl. Yacaranda, Sekip Unit IV Yogyakarta \\ Email Korespondensi: "braam.delfian@ugm.ac.id
}

Received : August $3^{\text {rd }}, 2020$; Accepted : September 26, 2020 ; Published : January $1^{\text {st }}, 2021$

\begin{abstract}
Abstrak
Miniatur adalah adalah tiruan sesuatu dalam ukuran yang sangat diperkecil dengan tingkat kepresisian dan kedetailan yang menyerupai benda aslinya. Salah satu miniatur yang biasa dibuat adalah miniatur alat transportasi khususnya bus dan salah satu produsennya adalah Kelompok Karang Taruna Dusun Bendungan yang terletak di Kecamatan Karangmojo Kabupaten Gunung Kidul. Pembuatan miniatur selama ini dilakukan secara manual dengan mangandalkan cutter sebagai alat pembentuk. Pada pembuatan secara manual terdapat beberapa kendala yang dihadapi yaitu kesulitan saat pembuatan master untuk cetakan yang meliputi master cetakan cowl, cetakan untuk seat, cetakan cover AC dan bagian lainnya. Selain itu pembuatan miniatur dengan cara manual memiliki kekurangan seperti tidak presisinya bentuk dan ukuran dengan benda aslinya serta jika terjadi perubahan kecil pada bagian tertentu maka harus melakukan pembuatan dari awal kembali. Berdasarkan kendala tersebut tim pengabdian memberikan solusi pemecahan dengan melakukan pembuatan mesin $3 D$ printer yang akan digunakan untuk mendukung produksi miniatur bus. Pembuatan mesin $3 D$ printer dengan dimensi $48 \times 46 \times 44 \mathrm{~cm}$ mendapat respon yang postif, selain itu dalam pelatihan yang dilakukan anggota sangat antusias dalam mengikuti. Pemanfaatan mesin $3 D$ printer sangat membatu proses produksi dan meningkatkan efisiensi waktu sebesar $76 \%$ pada tahap pembuatan master cetakan.
\end{abstract}

Kata Kunci: Gunung Kidul, miniatur, $3 D$ printing

\section{Abstract}

Replica is an imitation of an object in a size that is greatly reduced by the level of precision and detail that resembles the original object. One of the replica commonly made is a replica of transportation, especially buses, and one of the producers is Karang Taruna Dusun Bendungan, which is located in Karangmojo Subdistrict, Gunung Kidul District. Making replica so far has been done manually by relying on the cutter as a forming tool. In making manuals there are several obstacles faced, namely difficulties when making molds which include cowl molds, seat molds, AC cover molds and other parts. In addition, making miniature manually has disadvantages such as not being precise in shape and size with the original object and if there is a small change in a particular part, then it must be made from scratch again. Based on these constraints the team provided a solution by making a $3 D$ printer machine that could be used to support bus replica production. Making a $3 D$ printer machine with dimensions of $48 \times 46 \times 44 \mathrm{~cm}$ got a positive response. In addition, the conducted training were enthusistically participated by the members. Utilization of $3 D$ printer machines greatly helps the production process and increases the efficiency of time by $76 \%$ at the stage of making master prints.

Keywords : Gunung Kidul, replica, 3D printing 


\section{Pendahuluan}

Miniatur adalah potret atau lukisan dan patung berukuran kecil yang dibuat di atas berbagai permukaan dengan aneka ragam bentuk [1]. Sedangkan pengertian miniatur secara umum menurut Kamus Besar Bahasa Indonesia adalah tiruan sesuatu dalam ukuran yang sangat diperkecil [2]. Miniatur umumnya dibuat sebagai properti dalam suatu acara atau pameran, tetapi miniatur juga dapat dibuat dan dimiliki sebagai barang koleksi. Salah satu miniatur yang digunakan sebagai barang koleksi adalah miniatur alat transportasi.

Pembuatan miniatur di Indonesia termasuk kedalam salah satu jenis industri kreatif yang sedang berkembang pada zaman modern saat ini. Pada era modernisasi saat ini, industri kreatif tidak hanya mengandalkan kreatifitas secara manual, akan tetapi industri kreatif semakin berkembang dan meluas pada penggunaan teknologi. Salah satu teknologi yang diminati di kalangan masyarakat khususnya orang yang hobi dengan dunia miniatur adalah teknologi layer manufacturing. Pembuatan miniatur dengan teknologi layer manufacturing dapat menyingkat waktu dan memperoleh hasil mendekati sesuai model tiga dimensi (3D) yang dibuat oleh aplikasi Computer Aided Design (CAD). Jenis layer manufacturing yang digunakan untuk proses percetakan miniatur sasis bus adalah Fused Deposition Modelling (FDM) yang merupakan salah satu teknik rapid prototyping tipe additive [3]. Teknologi FDM atau yang sering dikenal dengan $3 D$ printer adalah mesin pembuat benda padat tiga dimensi dari sebuah desain secara digital menjadi bentuk 3D yang dapat dilihat tapi juga dipegang dan memiliki volume [4].

Salah satu produsen miniatur yang berada di wilayah Propinsi Daerah Istimewa Yogyakarta adalah Karang Taruna Dusun Bendungan yang berada disebuah desa deretan pengunungan Selatan Pulau Jawa yang termasuk dalam wilayah administratrif Desa Bendungan, Kecamatan Karangmojo, Kabupaten Gunung Kidul [5]. Salah satu kegiatan yang dilakukan karang taruna tersebut adalah bidang kegiatan kewirausahaan, salah satu bidang wirausaha yang dilakukan adalah industri pembuatan miniatur bus seperti pada Gambar 1.

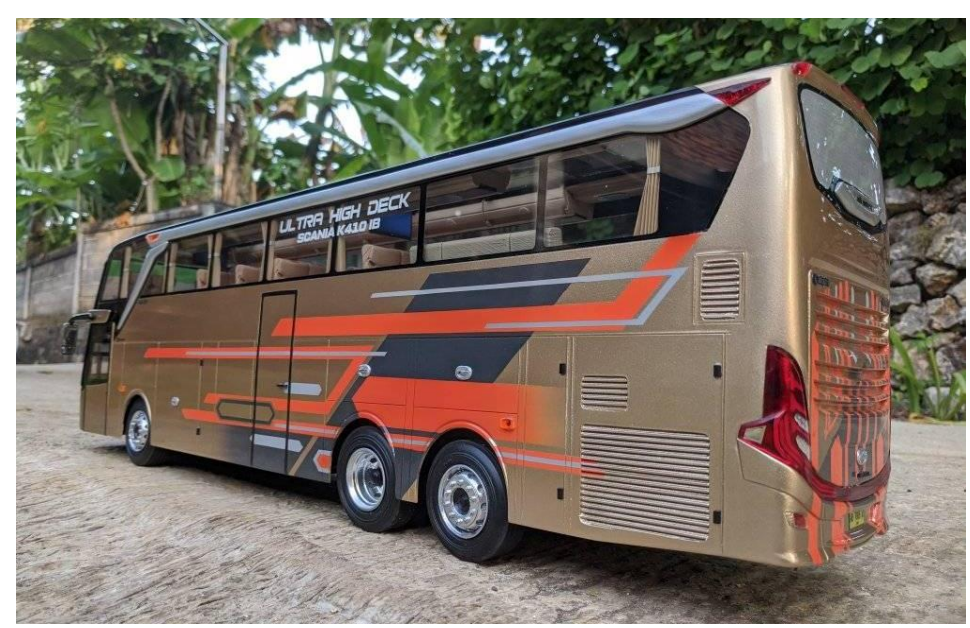

Gambar 1. Miniatur Bus Produk Karang Taruna Dusun Bendungan

Kegiatan produksi miniatur yang dilakukan Karang Taruna Dusun Bendungan yang dimotori oleh salah satu alumni Departemen Teknik Mesin SV-UGM selain dapat memberikan kontribusi pendapatan yang digunakan untuk menjalankan kegiatan karang taruna juga menjadi media transfer ilmu pengetahuan dan teknologi antar anggota dan steakholder. Proses pengerjaan miniatur dilakukan di rumah salah satu warga yang dijadikan workshop seperti terlihat pada Gambar 2. 

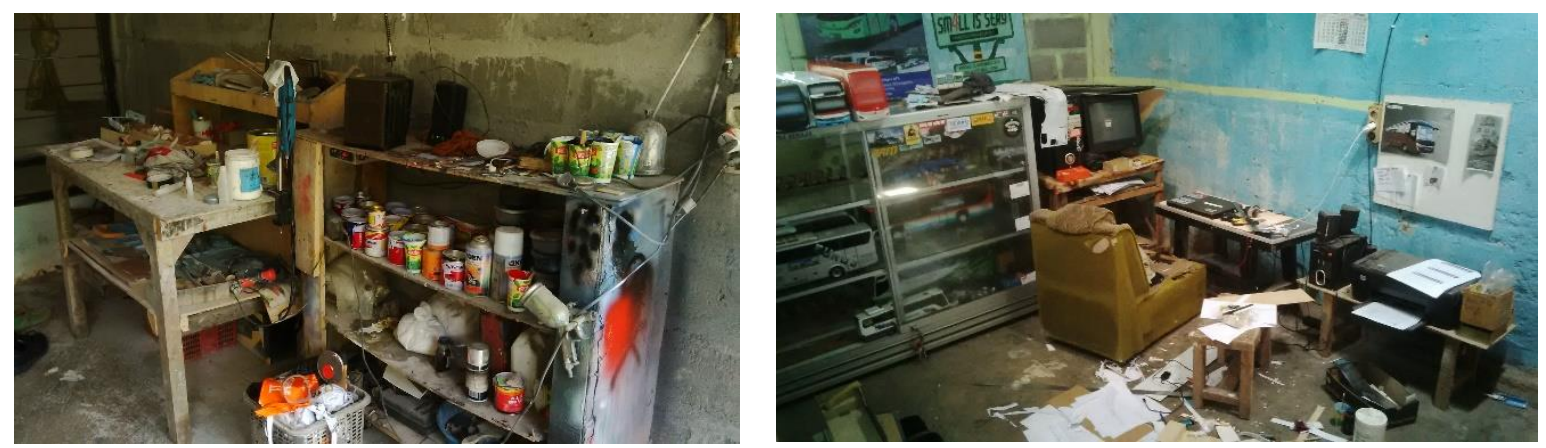

Gambar 2. Workshop Pembuatan Miniatur

Animo masyarakat terhadap miniatur bus yang cukup besar belum diimbangi dengan kemampuan produsen dalam membuat produk miniatur bus dalam waktu yang cepat dan bentuk yang presisi. Proses pembuatan miniatur bus selama ini masih dilakukan secara manual, mulai dari tahap awal, tahap merangkai, pengecatan, hingga finishing. Pada tahap awal khususnya saat proses pembuatan prototype cetakan sepeti cetakan cowl depan dan belakang hingga komponen pendukung lain seperti seat, spion, atau cover AC dilakukan dengan mengandalkan alat bantu berupa cutter dan keahlian sumber daya manusia dalam membentuk sesuai dengan bentuk aslinya. Proses pembentukan dilakukan secara manual dengan material kayu, triplek, atau acrylic lembaran yang di bentuk sesuai desain aslinya dengan menggunakan bantuan cutter atau alat potong konvensional lainnya. Miniatur bus hasil pembuatan secara manual disajikan pada Gambar 3.

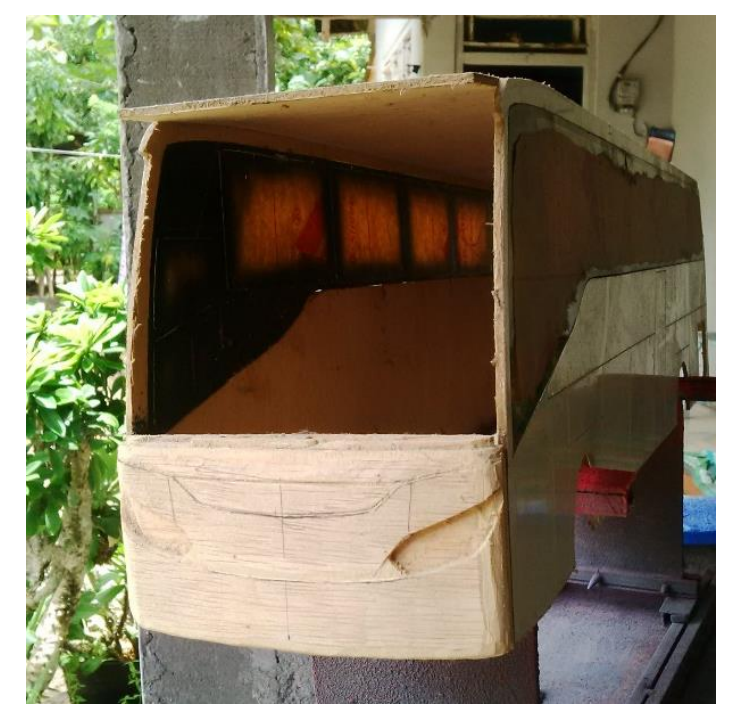

Gambar 3. Cowl Depan yang Dibuat secara Manual

Kendala yang selama ini dialami selama oleh Karang Taruna Dusun Bendungan dalam pembuatan miniatur bus adalah proses pembuatan prototyping untuk cetakan. Pembuatan prototyping cetakan secara manual memiliki kekurangan seperti tidak presisinya bentuk dan ukuran dengan benda aslinya. Selain itu, jika terjadi perubahan kecil pada bagian tertentu maka harus melakukan pembuatan prototyping cetakan dari awal. Disamping itu kemampuan membuat bagian secara manual hanya dapat dilakukan oleh beberapa anggota yang memiliki keahlian dan ketrampilan khusus. Prototyping akan sangat membantu menentukan proses produksi selanjutnya dan salah satu alternatif dalam pembuatan prototyping adalah dengan menggunakan mesin $3 D$ printer [6]. Selain digunakan untuk prototyping, penggunaan mesin $3 D$ printer digunakan untuk pembuatan komponen dengan tingkat variasi bentuk yang 
berbeda-beda dan dalam jumlah yang relatif sedikit, pembuatan cetakan rubber dianggap tidak efisien.

\section{Metode}

Dalam program pengabdian kepada masyarakat metode pelaksanaan yang diterapkan dalam memecahkan masalah tersebut adalah penerapan teknologi $3 D$ printer dalam produksi miniatur bus. Penerapan teknologi $3 D$ printer pada Karang Taruna Dusun Bendungan merupakan suatu rangkaian proses pengembangan produksi miniatur bus yang dimulai dari identifikasi kebutuhan, perancangan dan pembuatan mesin, pelatihan penggunaan hingga pendampingan yang berkelanjutan. Diagram alir kegiatan program pengabdian kepada masyarakat tersaji pada Gambar 4.

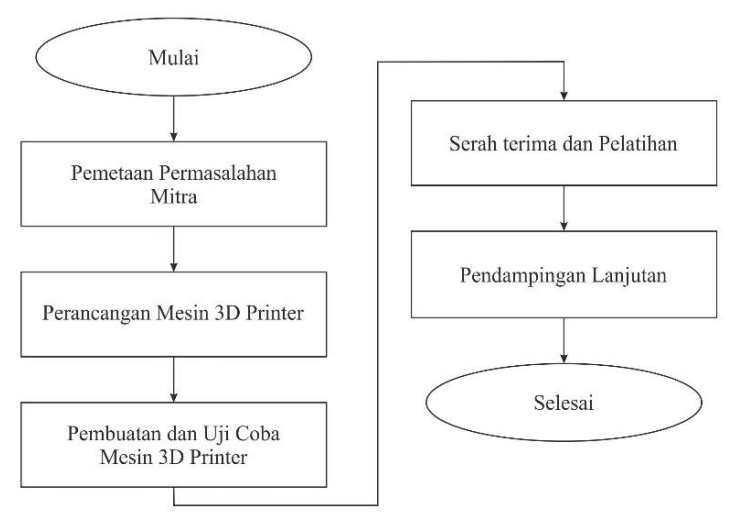

Gambar 4. Diagram Alir Kegiatan

Langkah-langkah dalam penerapan metode tersebut dilakukan mulai dari pemetaan awal masalah yang terdapat pada produksi miniatur bus. Dari hasil pemetaan awal diperoleh informasi bahwa salah satu kendala yang dihadapi oleh Karang Taruna Dusun Bendungan dalam memproduksi miniatur bus adalah permasalahan secara fisik dan dimensi. Permasalahan tersebut terjadi karena adanya perbedaan hasil komponen miniatur yang dibuat secara manual, baik secara dimensi maupun bentuknya. Guna memecahkan permasalahan tersebut maka dalam kegiatan pengabdian kepada masyarakat pada Karang Taruna Dusun Bendungan dimulai dengan melakukan perancangan dan pembuatan mesin $3 D$ printer. Berdasarkan informasi terkait proses produksi miniatur bus, dapat digunakan acuan untuk merancang dan membuat mesin tersebut. Desain awal mesin $3 D$ printer memiliki dimensi ( $\mathrm{p}$ x 1 x t) 48 x 46 x $44 \mathrm{~cm}$ seperti terlihat pada Gambar 5 .

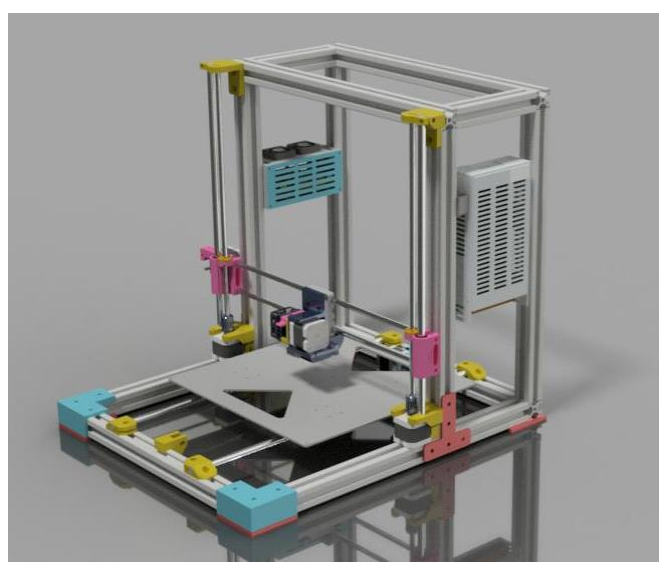

Gambar 5. Desain Mesin 3D Printer 
Sistem penggerak yang digunakan pada mesin $3 D$ printer ini adalah penggerak ekstruder, dimana ekstruder bergerak pada arah horizontal dan vertikal (sumbu X dan Z) dengan menggunakan motor steper serta sistem otomasi menggunakan mikrokontoller Arduino Mega. Dalam pembuatan mesin 3D printer terdapat pula beberapa komponen pendukung seperti power supply, LCD smart controller, lead screw, dan beberapa komponen lainnya.

Langkah berikutnya yang dilakukan setelah melakukan perancangan dan pembuatan mesin $3 D$ printer adalah kegiatan pelatihan penggunaan dan pendampingan berkelanjutan. Dalam memanfaatkan teknologi pada pembuatan miniatur bus diperlukan sumber daya manusia yang kompeten dalam pengoperasiannya. Melalui pelatihan diharapkan mereka dapat mengetahui cara pengoperasian mesin $3 D$ printer secara baik dan benar serta dapat melakukan perawatan yang sesuai. Selain pelatihan terkait pengoperasian, kegiatan pengabdian ini juga melakukan pendampingan terkait pengembangan produk yang dapat dilakukan dengan menggunakan mesin $3 D$ printer.

\section{Hasil dan Pembahasan}

Hasil kegiatan yang telah dicapai dalam kegiatan program pengabdian kepada masyarakat pada Karang Taruna Dusun Bendungan ini adalah pembuatan alat bantu produksi yang berupa mesin $3 D$ printer beserta pelatihan pengoperasian, serah terima alat, dan evaluasi hasil produk.

\subsection{Identifikasi Mitra}

Pengembangan industri kreatif yang dilakukan oleh kelompok masyarakat seperti kegiatan Karang Taruna Dusun Bendungan dalam pembuatan miniatur bus harus memperhatikan beberapa aspek. Hal-hal yang berpengaruh terhadap pengembangan industri kreatif terkait dengan aspek kekuatan, aspek kelemahan, aspek peluang, dan aspek ancaman [7]. Pada pembuatan miniatur bus yang dilakukan oleh Karang Taruna Dusun Bendungan aspek kekuatan yang dimiliki yaitu pangsa pasar yang potensial sehingga menjadikan sumber pemasukan yang menjanjikan bagi karang taruna sebagai produsen dan tersedianya sumber daya manusia berpengalaman dalam pembuatan miniatur. Sedangkan sisi kelemahan dan ancaman yang berpengaruh terhadap produksi tersebut adalah kecepatan dalam melakukan update model miniatur bus sesuai dengan model bus terbaru. Hal ini terkait terbatasnya sumber daya manusia yang dapat melakukan pembuatan prototyping cetakan secara manual. Selain itu persaingan antar produsen miniatur bus semakin ketat, sehingga perlu melakukan pengembangan supaya dapat tetap bersaing dengan produk lain. Dalam pembuatan miniatur bus yang dilakukan oleh Karang Taruna Dusun Bendungan memiliki peluang dalam hal pemanfaatan teknologi untuk pengambangan produk agar diperoleh produk yang detail dan mirip dengan aslinya. Pemanfaatan mesin $3 D$ printer pada produksi miniatur bus oleh Karang Taruna Dusun Bendungan akan melengkapi pemanfaatan ilmu pengetahuan dan teknologi yang sudah ada sebelumnya yaitu pembuatan desain dengan komputer, proses pengecatan dengan menggunakan kompresor, dan penghalusan permukaan dengan menggunakan mesin.

\subsection{Mesin 3D Printer}

Hasil yang diperoleh dari pengabdian ini adalah dibuatnya mesin $3 D$ printer untuk membantu produksi miniatur yang dilakukan Karang Taruna Dusun Bendungan. Pada pembuatan mesin $3 D$ printer dilakukan dalam beberapa bagian yang meliputi bagian frame, mekanisme gerak dan sistem penggerak serta otomasi. Pembuatan rangka dilakukan dengan menggunakan alumunium profil 2020 dengan dimensi ( $\mathrm{p}$ x 1 x t) adalah 48 x 46 x $44 \mathrm{~cm}$ dengan konektor antar bagian menggunakan plat siku dengan screw. Mekanisme gerak pada 
mesin $3 D$ printer menggunakan komponen motor steper NEMA-17, lead screw, pulley, dan belt. Sedangkan untuk sistem otomasi menggunakan komponen mikrokontoller Arduino Mega 2360, power supply, driver DRV 8825, dan LCD smart controller sebagai sarana untuk menampilkan informasi tentang mesin $3 D$ printer. Bentuk mesin $3 \mathrm{D}$ printer beserta dengan komponen tersaji pada Gambar 6.

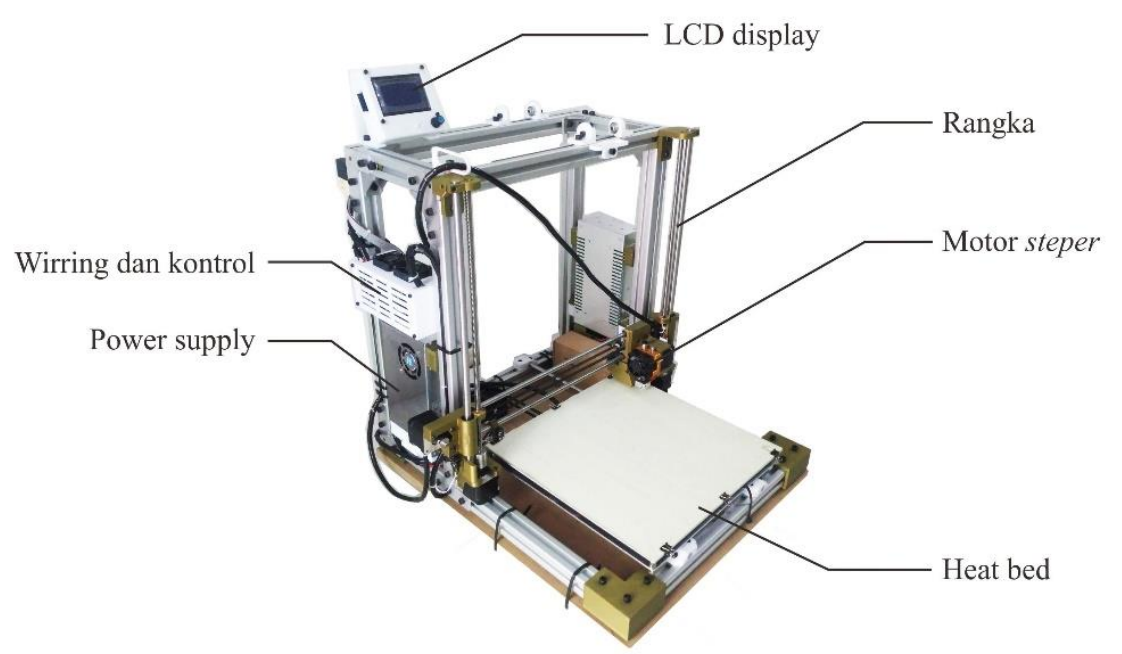

Gambar 6. Mesin 3D Printer

\subsection{Pelatihan}

Kegiatan yang dilakukan setelah mesin $3 D$ printer selesai dibuat adalah pelatihan pengoperasian, perawatan, dan troubleshooting. Pelatihan dilakukan di Kampus Departemen Teknik Mesin Sekolah Vokasi UGM dengan menghadirkan anggota Karang Taruna Dusun Bendungan dan kerena keterbatasan waktu dalam pelaksanaan, maka pelatihan ini dilakukan secara berantai dimana pada pelatihan pertama salah satu anggota datang untuk mengikuti pelatihan seperti terlihat pada Gambar 7.

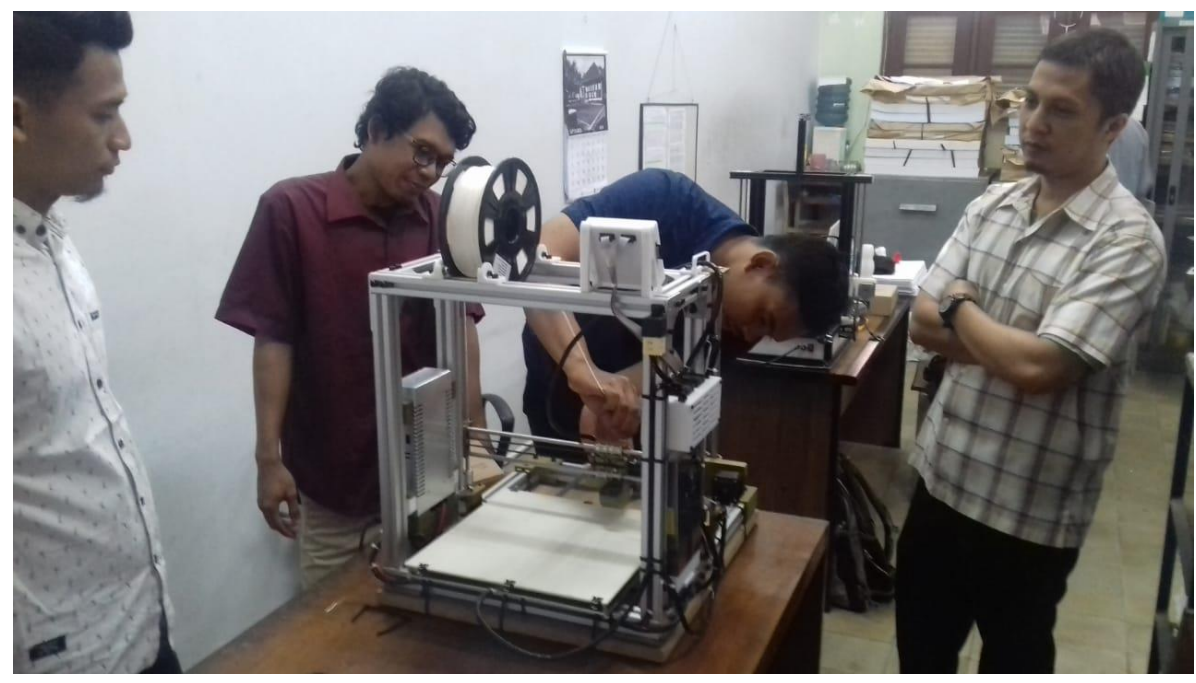

Gambar 7. Suasana Pelatihan Mesin Penggunaan 3D Printer

Selanjutnya anggota tersebut yang akan melakukan transfer ilmu terhadap anggota lainnya dengan pendampingan dari tim pengabdian. Pelatihan dilakukan dengan mengenalkan mesin $3 D$ printer beserta cara mengoperasikan serta dilakukan uji coba pembuatan produk dengan filament polylactid acid (PLA). Pada sesi ini juga diberikan teknik dalam merawat dan troubleshooting jika terjadi gangguan pada operasi mesin tersebut. Disamping pelatihan 
teknis, tim pengabdian kepada masyarakat juga melakukan pendampingan terkait proses produksi dan manajemen pengelolaan serta saran untuk pengembangan kedepannya.

\subsection{Hasil Produk 3D Printer}

Dengan menggunakan mesin $3 D$ printer, pembuatan komponen miniatur bus menjadi lebih akurat dan presisi serta lebih mudah melakukan modifikasi jika terdapat kesalahan atau modifikasi terhadap suatu part. Dari sisi waktu pembuatan juga terdapat efisiensi waktu dalam pembuatan prototyping cetakan cowl, seat, dan velg. Jika membuat prototyping cetakan cowl depan dengan cara manual membutuhkan waktu sekitar 30 hari, dengan menggunakan mesin $3 D$ printer pembuatan hanya membutuhkan waktu tujuh hari sehingga diperoleh efisiensi waktu sebesar $76 \%$ pada tahap pembuatan prototyping cetakan. Hal tersebut dapat tercapai karena pembuatan prototyping cetakan dengan penggunaan teknologi $3 D$ printer hanya perlu melakukan perbaikan pada gambar desain jika terjadi kesalahan dan saat proses pencetakan dapat digunakan untuk melakukan kegiatan produksi lainnya. Penggunaan teknologi $3 D$ printer dalam pembuatan miniatur dapat menghemat waktu serta memperoleh hasil yang mendetail sehingga teknologi $3 D$ printer merupakan solusi dalam pengembangan produk khususnya untuk memecahkan permasalahan lead time design process [8]. Perbandingan hasil pembuatan prototyping cetakan cowl depan dengan secara manual dan $3 D$ printer dapat dilihat pada Gambar 8.



(a)

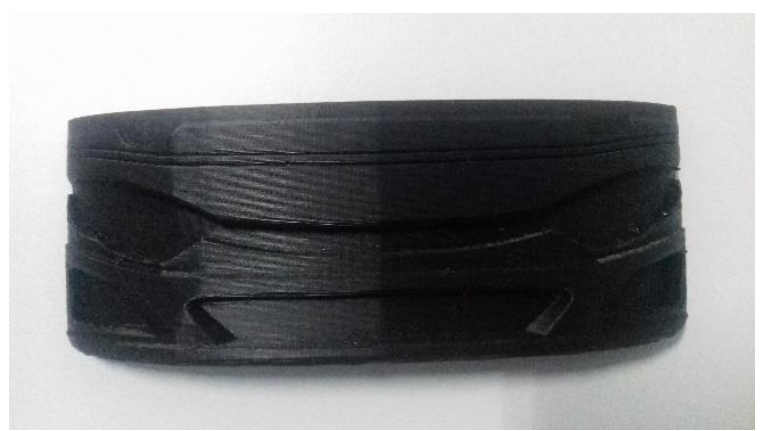

(b)

Gambar 8. Prototyping Cetakan Cowl Depan (a) Pembuatan Secara Manual, (b) Pembuatan Dengan 3D Printer

Efisiensi lain yang diperoleh dalam penggunaan teknologi $3 D$ printer adalah efisiensi pada sisi ekonomi. Harga material PLA dengan berat $1 \mathrm{~kg}$ dijual dengan harga rata-rata Rp. 250.000,00 maka penggunaan teknologi $3 D$ printer pada pembuatan miniatur bus jika digunakan untuk membuat prototyping cetakan cowl depan dan belakang membutuhkan PLA sebanyak 45 gram dan 95 gram. Jika pembuatan dilakukan dengan jasa pihak ketiga dimana biaya bahan dan produksi per 1 gram material PLA adalah Rp. 3.000,00 sehingga untuk pembuatan master cetakan cowl depan dan belakang dibutuhkan biaya Rp. 420.000,00. Sedangkan jika produsen sudah memiliki mesin $3 D$ printer dan melakukan pencetakan sendiri hanya diperlukan biaya bahan senilai Rp. 35.000,00 per sekali pembuatan prototyping cetakan cowl depan dan belakang. Biaya listrik yang diperlukan untuk operasional mesin ini tidak terlalu besar, dengan daya listrik rumah tangga 900 watt sudah dapat digunakan untuk mengoperasikan mesin $3 D$ printer dalam kondisi normal. Jika dibandingkan dengan harga jual miniatur bus produksi Karang Taruna Dusun Bendungan yang berada pada kisaran Rp. 2.000.000,00 per unit, maka secara nilai ekonomi penggunaan teknologi $3 D$ printer pada pembuatan miniatur bus sangat menguntungkan baik untuk pembuatan master cetakan maupun komponen pendukung lainnya. 
Nilai lebih pemanfaatan teknologi $3 D$ printer selain nilai efisiensi waktu yang sangat baik dan hasil yang detail serta nilai ekonomis yang tinggi, kelebihan lainnya adalah nilai kekuatan baik serta defleksi yang rendah. Dari hasil pengujian dengan metode elemen hingga diperoleh nilai tegangan maksimum produk hasil teknologi $3 D$ printer dengan material PLA sebesar 2,407 $\mathrm{MPa}$, dan nilai defleksi maksimum sebesar 0,7696 $\mathrm{mm}$ [9]. Nilai tegangan maksimum yang dihasilkan pada pengujian dengan study kasus chasis miniatur bus dikatakan aman karena nilai tersebut jauh dari nilai tegangan luluh PLA sebesar 59 Mpa [10]. Pendampingan terus dilakukan untuk meningkatkan kualitas produk hasil $3 D$ printer yang akan digunakan dalam pembuatan komponen miniatur bus. Peningkatan kualitas dapat dilakukan degan melakukan pengaturan parameter operasi dari mesin $3 D$ printer, dimana parameter print speed, layer height, dan temperatur ekstruder merupakan parameter yang dapat mempengaruhi kekuatan produk hasil 3D printer [11]. Contoh komponen miniatur bus yang dapat dibuat dengan teknologi $3 D$ printer adalah miniatur velg yang tersaji pada Gambar 9.

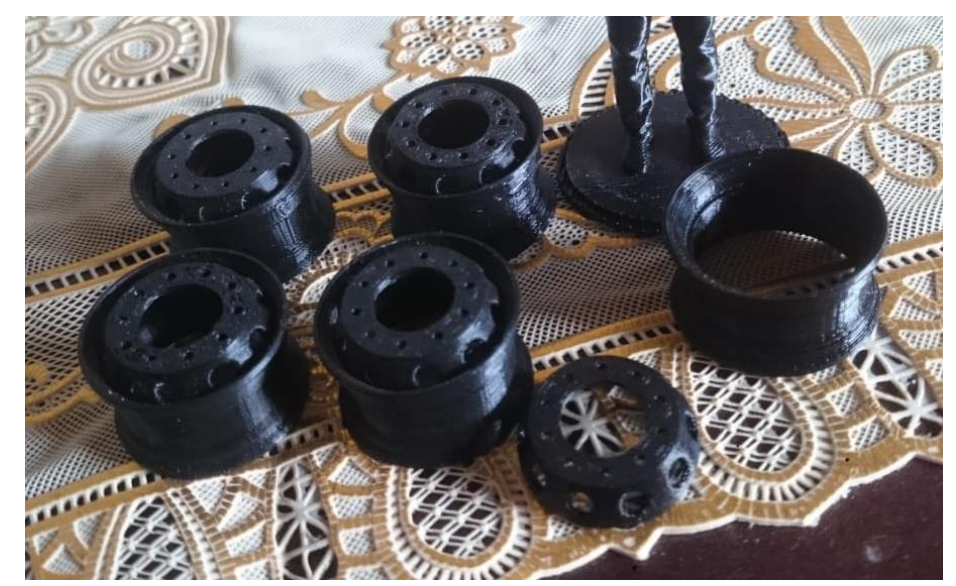

Gambar 9. Velg Miniatur Hasil 3D Printer

\section{Kesimpulan}

Program pengabdian yang dilaksanakan di Karang Taruna Dusun Bendungan telah berhasil memberikan solusi terhadap permasalah dalam pembuatan miniatur bus. Pembuatan mesin $3 D$ printer telah dilakukan dengan dimensi $48 \times 46 \times 44 \mathrm{~cm}$ serta telah beroperasi dengan baik. Pemanafaatan teknologi $3 D$ printer pada proses produksi miniatur bus diperoleh nilai efisiensi waktu hingga $76 \%$ khususnya pada proses pembuatan master cetakan dengan tingkat kepresisian yang tinggi dan memiliki nilai ekonomis yang baik.

\section{Daftar Pustaka}

[1] M. Susanto, Diksi Rupa, Yogyakarta: Kanisius, 2002.

[2] Poerwadarminta, Kamus Besar Bahasa Indonesia, Jakarta: Balai Pustaka, 1993.

[3] D. Yagnik, "Fused Deposition Modeling - A Rapid Prototyping Technique for Product Cycle Time," IOSR Journal of Mechanical and Civil, pp. 62-68, 2014.

[4] M.D. Muliyawan, G.E. Pramono, and Sumadi, "Rancang Bangun Konstruksi Rangka Mesin 3D Printer Tipe Cartesian Berbasis Fused Deposition Modeling (FDM)," Jurnal Teknik Mesin, vol. 06, no. 4, p. 252-257, 2017.

[5] Pemerintah Desa Bendungan, Kecamatan Karangmojo, Kabupaten Gunung Kidul 2018, http://bendungan-karangmojo.desa.id.

[6] M. Dahlan, B. Gunawan, and F.S. Hilyana, Rancang Bangun Printer 3D Menggunakan Kontroller Arduino Mega 2560, Prosiding SNATIF Ke-4, ISBN: 978-602-1180-50-1, 2017. 
[7] A.D. Ananda and D. Susilowati, Pengembangan Usaha Mikro Kecil dan Menengah (UMKM) Berbasis Industri Kreatif di Kota Malang, Jurnal Ilmu Ekonomi, vol X, jilid X, p. 120-142, 2017.

[8] K.S. Putra and U.R. Sari, Pemanfaatan Teknologi 3D Printing Dalam Proses Desain Produk Gaya Hidup, Seminar Nasional Sistem Informasi dan Teknologi Informasi 2018, 2018.

[9] B.D. Prihadianto and A.R. Koswara, "Analisis Kekuatan Miniatur Sasis Bus Hasil Teknologi Fused Deposition Modelling Dengan Metode Elemen Hingga," MANUTECH Jurnal Teknologi Manufaktur, vol.12, no. 1, p. 36-43, 2020.

[10] S. Farah, D.G. Anderson, and R. Langer, "Physical and mechanical properties of PLA, and their functions in widespread applications - A comprehensive review," Advanced Drug Delivery Reviews, vol.107, p. 367, 2016.

[11] A. Setiawan, "Pengaruh Parameter Proses Ektrusi 3D Printer Terhadap Sifat Mekanis Cetak Komponen Berbahan Filament PLA (Polylactide Acid)," Jurnal teknika STTKD, vol. 4, no. 2, p. 20-27, 2017. 
Braam Delfian Prihadianto, Suryo Darmo 